\title{
Federal Hiring of Graduates of Political Science and Public Administration Programs
}

\author{
Robert E. Cleary, The American University
}

Is federal employment a significant option considered by college graduates with degrees in the fields of political science or public administration when they look for work? This study examines this issue and such subsidiary questions as: Where do those who accept federal employment in the executive branch of the U.S. government go? Do they enter a range of agencies? At what grade levels are they hired? What occupations do they accept? Are they on a management track? Do they tend to go into administrative positions? Or professional ones? Do they take clerical jobs?

A quarter century ago Frederick C. Mosher observed that: "The higher officials in the public service are products of the colleges and universities and principally their professional departments and schools. ... [T]he nature and quality of the public service depends principally upon . . . education. Almost all of our future public administrators will be college graduates. . ." (Mosher 1968, 217-19).

While Mosher's prediction has proven to have substantial validity, problems have been associated with federal efforts to hire college graduates. The Volcker Commission recently called attention to the federal government's difficulties in attracting new college graduates (U.S. National Commission on the Public Service [NCPS] 1990, 23-27). The Commission's Task Force on Recruitment and Retention concluded that issues of recruitment and retention were the basis of a crisis in the federal government. Given this analysis, the Commission recommended that the government "enhance [its] efforts to recruit top college graduates and those with specific professional skills for government jobs" (NCPS 5). The Task Force strongly recommended that the government "meet the challenge of recruiting college graduates aggressively"' (NCPS
128). The Office of Personnel Management was advised to "simplify, expand, and clarify federal hiring activities" and to give federal recruiters more flexibility (NCPS 128).

In recent years, some 65,000 to 95,000 full-time civilian employees have been hired by the executive branch of the federal government (including independent agencies) per year. Fewer than $40 \%$ of those hired each year enter professional or administrative positions. A very small percentage are trained in public administration or in political science.

In fiscal year 1990, for example, 92,065 people (including student trainees and seasonal employees) were hired for full-time civil service positions in the executive branch, according to the U.S. Office of Personnel Management (OPM). Of this number, 19,288 took positions in occupations classified as professional, 15,649 in occupations classified as administrative, 13,880 in technical occupations, 35,968 in clerical, and 7,326 in other occupations (double classification accounts for the extra 46 people in the total). Of the new hires, 36,225 were college graduates (U.S. Office of Personnel Management [OPM] 1991b, 455).

Approximately 600 of these individuals earned degrees in political science (mostly bachelors); around 230 in public administration (mostly masters) (OPM 1991a).

\section{The Study}

In the fall of 1991 I explored the pattern of federal hiring of individuals educated in the fields of political science and public administration. I asked OPM to compile summary tables on civil service hires in fiscal years 1989 and 1990. I requested the total number of full-time hires for these two years, the level of educational attainment, the number of men and women, the number of minorities, the average GS-grade level, the employing agency, occupation, and the PATCO classification (i.e., professional, administrative, technical, clerical, or other). OPM provided me with summary data and with totals, but not with individual files, in order to preserve employee confidentiality (OPM 1991a).

\section{Findings}

\section{Political Science: 1989-90}

In the 1989 and 1990 fiscal years, the federal government hired just 1,206 new civil service employees with degrees in political science. Of this number, 901 (74.7\%) held bachelor's degrees; $97(8.0 \%)$ had done some work beyond the bachelor's; $185(15.4 \%)$ had earned master's degrees; and 23 (1.9\%) possessed doctorates. Of the total, $702(58.2 \%)$ were men, and 504 $(41.8 \%)$ were women. Two hundred and fifty-six $(21.2 \%)$ were listed as minorities.

Approximately half the new employees went into five federal agencies, with the remainder entering 44 different agencies. A total of 190 took employment in the Department of the Treasury, 125 in Health and Human Services (HHS), 112 in Justice, 78 in the Department of the Army, and 77 in the Department of the Navy.

There was some patterning to the jobs accepted, although the new political science hires were listed under 152 different occupational codes. In the largest employer, Treasury, 51 of the new political science employees ( $27 \%$ of the total Treasury hires) took positions coded as \#592 tax examiners, but the remainder split among 33 other occupational codes, with 24 being the next highest number, in code $\# 1811$ criminal investigator, followed by 22 , in code \#962 contact representative. 
In HHS, 38 of the new political science employees entered \#105 social insurance administration and 16 became \#993 social insurance claims examiners, but the remaining new political science hires went into 24 different occupations. In Justice, 18 became \#950 paralegal specialists, with the remainder going into 17 other occupations. The Office of Personnel Management hired 59 new political scientists in 1989-90, with 40 becoming \#1810 general investigators.

Regardless of agency, only a few occupations attracted many political science graduates. The 1,206 new political scientists entered a total of 152 different occupations, with only 31 categories attracting as many as ten each. The leading categories were as follows: 113 took jobs in code \#301 miscellaneous administration and program, 59 in \#1810 general investigating, 57 in \#1811 criminal investigating, 51 each in \#318 secretary and \#592 tax examining, and 42 in \#345 program analysis.

Of the 1,206 new political science graduates hired by the federal government in 1989 and 1990, most $(735$, or $60.9 \%)$ took positions coded under the PATCO scheme as administrative. Just $69(5.7 \%)$ took professional positions. A total of $71(5.9 \%)$ took technical jobs; $107(8.9 \%)$ took clerical jobs; and $44(3.6 \%)$ were classified as other. Double codings made up the remaining totals. Included in the administrative column were four of the six largest occupational categories listed above, except the secretaries, who are coded as clerical, and the tax examiners, who are listed as technical and clerical.

The 1,206 new political scientists entered government service at an average GS-grade of 7.6. The 998 bachelor's degree holders entered at an average grade of 7.2 ; the 185 master's degree holders at an average grade level of 9.2; and the 23 doctoral degree holders at an average grade level of 12.5 .

\section{Public Administration: 1989-90}

In the 1989 and 1990 fiscal years, the federal government hired only 462 new civil service employees with degrees in the field of public administration. A total of $301(65.2 \%)$ of this number held master's degrees, with all but one of the remainder holding bachelor's degrees. Two hundred and eighteen $(47.2 \%)$ were men, and $244(52.8 \%)$ were women. One hundred and twenty-three $(26.6 \%)$ were listed as minorities.

Approximately half the new public administration employees went into just five federal agencies, with the remainder entering 27 other agencies. A total of 82 took employment in the Department of Health and Human Services, 52 in the Environmental Protection Agency, 37 in Justice, 30 in the National Aeronautics and Space Administration, and 27 in the Department of the Army.

There was a little clustering to the jobs accepted, but not very much. In HHS, 40 of the 82 new PA employees took positions in \#301 miscellaneous administration and program, but the remainder split among 18 other codes, with seven being the next highest number (both in code \#105 social insurance administration and in \#345 program analysis). In the EPA, 22 public administration majors accepted positions as \#028 environmental protection specialists, while 18 went into $\# 345$ program analysis. In Justice, the 37 new PA employees split among 15 job codes, with nine being the highest number (in \#007 correctional officer). In NASA, 23 of the 30 new hires took positions in code \#301 miscellaneous administration and program. On the other hand, the 27 new Army public administration graduates split among 22 job codes, with five going into \#2001 general supply. Overall, the 462 new hires went into 100 different occupational codes.

Nevertheless, when analyzed as a whole, most of the new public administration majors went into a small number of federal occupations. Half took positions in only seven occupations. Ninety-five took jobs in code \#301 miscellaneous administration and program, 45 in \#345 program analysis, 22 as \#028 environment protection specialists, 20 each as \#560 budget analysts and \#1102 contracting officers, 18 in \#201 personnel management, and 14 in \#343 management analysis.

A total of $332(71.9 \%)$ of the 462 new PA employees took positions coded under the PATCO scheme as administrative. Included in the administrative column were six of the seven largest categories listed above, except the contracting officers, who are coded as professional. Only 42 $(9.1 \%)$ took professional positions. Fifteen $(3.2 \%)$ took technical jobs, $24(5.2 \%)$ clerical positions, and twelve $(2.6 \%)$ jobs coded as other.

The 462 new PA employees entered government service at an average GS-grade of 8.8 . The 160 bachelor's degree holders entered at an average grade of 7.3 , while the 301 master's degree holders entered government service at an average grade level of 9.0 .

\section{Comparisons with}

\section{Selected Other Disciplines}

When I requested the Office of Personnel Management to compile summary tables on federal government hires in political science and public administration, I also asked for data on hires in history, economics, law, and physics for comparison purposes (physics was included to allow some comparisons with a field outside social science).

Comparisons between political science and public administration on the one hand and the additional fields on the other were most interesting with regard to the entering grade level of new employees. The new hires in political science and public administration entered federal government service in 1989-90 at an average grade level slightly below the average for new lawyers, physicists, and economists at comparable educational levels, but at a higher level than people with degrees in history. This pattern holds for all four other disciplines at both the bachelor's degree and the master's levels. It also holds for most comparisons at the doctoral level, except that the political science Ph.D.s in 1989-90 entered the federal government at a higher average grade level than Ph.D.s in law or Ph.D.s in history.

On another comparison-the type of position accepted-political science, public administration, and history graduates tended to accept federal jobs coded as administrative, while graduates with degrees in law, physics, and, to a lesser extent, eco- 
nomics, accepted positions coded as professional. A total of $735(60.9 \%)$ of the new political science hires in 1989-90 took administrative positions, as did $332(71.9 \%)$ of the new public administration hires and 326 $(44.8 \%)$ of the new historians. This compared with $290(11.7 \%)$ of the new lawyers, $39(8.5 \%)$ of the new physicists, and $340(37.3 \%)$ of the economists. The comparable figures for professional positions are: political science, $69(5.7 \%)$; public administration, $42(9.1 \%)$; history, 88 (12.1\%); law, 2,061 (83.2\%); physics, $399(86.7 \%)$; and economics, $420(46.1 \%)$.

\section{Comments}

The number of new political science and public administration graduates hired by the federal government is extremely small. Only $1 \%$ of the new federal civil service employees hired in 1989-90 held political science or public administration degrees -about 600 people per year in political science and 230 each year in public administration.

Just over $40 \%$ (504) of the new political scientists hired in 1989-90 were women, with about $20 \%$ (256) being minorities. More than half of the public administration hires were women $(52.8 \%$, or 244$)$, while $26.6 \%$ (123) were minorities.

Few graduates of political science and public administration programs go into the federal civil service. The American Political Science Association reports, for example, that in the 1989-90 academic year some 47,600 individuals graduated from colleges and universities with degrees in politjcal science ( 575 with doctoral degree, 2,884 with master's, and 44,123 with bachelor's) (Brintnall 1992). A little over 1\% of this number entered federal employment in 1989-90 (OPM 1991a). Similarly, the National Association of Schools of Public Affairs and Administration (NASPAA) reports that in 1988-89 some 8,500 people earned degrees in public administration (an estimated 1,500 to 2,000 at the bachelor's level, 6,587 at the master's, and 219 at the doctoral level; see National Association of Schools of Public Affairs and Administration [NASPAA] 1990,
20-21). According to OPM, less than $3 \%$ of this number entered the federal government in 1989-90 (OPM 1991a).

The political scientists who enter federal service tend to be bachelor's degree holders; the public administration graduates tend to be master's degree holders.

The agencies who hire the most employees also hire many of the political science and public administration graduates who go into the federal government. Lewis's data $(1987,1991)$ show that the largest federal employers between 1974 and 1989 were Army, Treasury, Veterans Administration (VA), Navy, HHS, Agriculture, Air Force, and Justice. Except for the Department of Agriculture (where hiring-with the exception of \#301 miscellaneous administration and program-tends to be specialized; see \#120 food assistance program specialist, for example), the largest agency hirers included a sizable number of political science and public administration graduates in their totals. Thus the Army was the fifth largest employer of new PA graduates and the fourth largest of new political scientists in 1989-90. The comparable standings for Treasury were seventh and first; for the VA eighth and eleventh; for Navy sixth and fifth; and so on.

Few new political science and public administration graduates entering federal service found positions coded as professional by the federal government. Moreover, the number is declining.

A significant percentage of the new political science and public administration hires $(61 \%$ of the political scientists and $72 \%$ of the public administration graduates hired in 1989-90) went into occupations coded by OPM as administrative. Some of these positions are administrative-assistant type jobs; see, for example, \#301 miscellaneous administration and program and \#501 financial administration and program. Others are analyst positions; see, for example, \#105 social insurance administration, \#343 management analysis, and $\# 560$ budget analysis. While these positions are not necessarily management jobs, they are often likely to put their occupants on a management track. It is interesting to note, for example, that new political scientists and public administration specialists are entering jobs in code \#301 miscellaneous administration and program (coded as administrative), as opposed to \#303 miscellaneous clerk and assistant (coded as clerical and technical).

Many of the largest relevant new job categories in the federal government did not attract substantial numbers of new political scientists or public administrators. In 1989, the assistant director of OPM for Workforce Information reported on selected high-demand occupations in the federal workforce with direct relevance to public administration in the mid-1980 years (Schneider 1989). These included code \#346 logistics management, with a $333 \%$ increase in employment between 1974 and 1987 , but with only two new hires in political science and public administration in 1989-90; \#501 financial administration and program, $251 \%$, versus six; \#345 program analysis, $108 \%$, versus 87 ; \#080 security administration, $105 \%$, versus fifteen; \#1810 general investigating, $103 \%$, versus 62; \#334 computer specialist, $83 \%$, versus five; \#1102 contracting, $79 \%$, versus 47; \#343 management analysis, $72 \%$, versus 27 ; \#340 program management, $68 \%$, versus two; and $\# 560$ budget analysis, 58\%, versus 47 . It should be noted that the data utilized to make the comparisons here are for different sets of years, with the early and mid1980s being part of the Reagan defense build-up and 1989-90 being after the end of that expansion. Given this situation, the comparisons are not as stark as they may seem at first glance. The category of logistics management, e.g., did not include as many new hires per year in 1989-90 as it did in 1974-87. Nevertheless, substantial numbers of people continue to be employed in occupations like financial administration and program, computer specialist, and security administration. While some fields with low numbers of new political science and public administration hires require particular or specialized knowledge, an occupation like security administration, for just one example, can certainly be filled by graduates in these fields. 


\section{Conclusion}

New college-educated employees may be making substantial contributions to government (see, e.g., Newcomer et al. 1989 and Newcomer, Johnson, and Naccarato 1990 on the Presidential Management Internship program), but an analysis of the demography of new hires in the executive branch indicates clear limits on the possible impact by new political science and public administration graduates on the federal public service. Perhaps APSA, ASPA, NASPAA, and other organizations and individuals interested in improving the public service should increase their efforts to expand the number of graduates in these fields entering the civil service. In addition, an interesting question for further research would require a longitudinal study to determine the employment pattern of graduates in political science and public administration after a few years employment. Do these graduates move into higher levels of administrative responsibility more or less quickly than do graduates in other fields?

Given the numbers noted in this study, if there is to be a significant contribution to effective and responsible government by new hires in political science and public administration, it is more likely to come because of the nature of the education our graduates receive in our educational programs. Consequently, we may well be advised to review the content of our programs from this perspective (see, e.g., Cleary 1990). Furthermore, we may need to em- phasize in such reviews criteria for evaluating how those young people specializing in political science and public administration who enter public service can make a contribution to effective and responsible government.

One final thought: Opportunities for women and minorities in federal employment are increasing, albeit slowly. This situation reinforces the utility of affirmative action programs on campuses, and offers a target of opportunity for increasing the impact of education in political science and public administration on the federal service now. More and better efforts may be called for in this regard.

\section{Note}

The author wishes to thank Philip A. D. Schneider and Andrew P. Klugh of the U.S. Office of Personnel Management for their assistance in providing the data reported on in this paper.

\section{References}

Brintnall, Michael. 1992. Letter and Tables. American Political Science Association. Typescript and photocopies.

Cleary, Robert E. 1990. "What Do Public Administration Masters Programs Look Like? Do They Do What Is Needed?" Public Administration Review 50: 663-73.

Lewis, Gregory B. 1987. "How Much Is an MPA Worth? Public Administration Education and Federal Career Success." International Journal of Public Administration 9: $397-415$.

Lewis, Gregory B. 1991. "Origin File." American University. Computer Printout.

Mosher, Frederick C. 1968. Democracy and the Public Service. New York: Oxford
University Press.

National Association of Schools of Public Affairs and Administration. 1990. Programs in Public Affairs and Administration: 1990 Directory. Washington, DC: NASPAA.

Newcomer, Kathryn E., Gail Johnson, and Tom Naccarato. 1990. "Successful Recruitment and Retention: The Presidential Management Internship Program." The Bureaucrat 19: 35-39.

Newcomer, Kathryn E. et al. 1989. "The Presidential Management Internship Program: Looking Backward and Moving Forward." Public Administration Review 49: $372-86$.

Schneider, Philip A. D. 1989. "Public Administration Graduates in the Public Service." Presented at the annual conference of the Northern Virginia Chapter of the American Society for Public Administration.

U.S. National Commission on the Public Service [the Volcker Commission]. 1990. Leadership for America: Rebuilding the Public Service. The Report of the National Commission on the Public Service. Lexington, MA: Lexington Books.

U.S. Office of Personnel Management. 1991a. "GS-GM New Hires." Computer Printout.

U.S. Office of Personnel Management. 1991b. "Occupational Series Dynamics: Full-Time Permanent General Schedule and Equivalent.' Computer Printout.

\footnotetext{
About the Author

Robert E. Cleary is professor of public affairs at American University, where he was dean of the College of Public Affairs from 1980 to 1987 . He is a past president of the National Association of Schools of Public Affairs and Administration. His most recent publication is "Revisiting the Doctoral Dissertation in Public Administration: An Examination of the Dissertations of 1990," Public Administration Review, January/ February 1992.
} 